\title{
Um mundo de coisas mais competentes que nós: abrindo caixas pretas através de uma semiótica material em Vilém Flusser
}

\author{
Mauricio de Souza Fanfa \\ Doutorando; Universidade Federal de Santa Maria, Santa Maria, RS, Brasil \\ mauriciofanfa@mail.ufsm.br

\section{Phillipp Dias Gripp} \\ Doutor; Universidade Federal de Santa Maria, Santa Maria, RS, Brasil \\ phidgripp@gmail.com
}

\begin{abstract}
Resumo
Os estudos sobre a construção social da ciência e tecnologia são atentos a caixas pretas e seus funcionamentos. Tem-se sugerido a noção de semiótica material como agregadora da necessidade de recorrência a considerações sobre a materialidade dos objetos evocados para análise. No presente texto, buscamos argumentar sobre como Vilém Flusser pode ser retroativamente considerado um pensador que trata de aspectos da semiótica material e sobre como sua perspectiva crítica pode contribuir com tal vertente. Por fim, para ilustrar nosso esforço, realizamos o que pode ser chamado de uma análise de semiótica material de inspiração flusseriana acerca do aparelho smartphone e a função Stories no aplicativo Instagram. Concluiu-se que uma semiótica material de inspiração flusseriana é aquela que busca examinar como se desenvolve um tipo de pensamento infrahumano nas associações heterogêneas.
\end{abstract}

\section{Palavras-chave}

Vilém Flusser. Semiótica material. Caixa preta. Smartphone.

\section{Introdução}

Vilém Flusser, 1920-1991, filósofo checo-brasileiro, foi professor na Universidade de São Paulo e viveu no Brasil entre os anos 1940 e 1970. Dedicou muito de sua produção intelectual à comunicação, ao design e à tecnologia. Os três temas, desde a época de Flusser até os dias de hoje, mostram-se cada vez mais entrelaçados e tratam dos elementos 
materiais do mundo ao nosso redor. Sua extensa produção sobre a temática se tornou relevante para os debates filosóficos de tais áreas.

Neste artigo, propomos argumentar que Vilém Flusser pode ser considerado, retrospectivamente, um pensador atento aos aspectos característicos e essenciais do que hoje tem se chamado de semiótica material. A semiótica material é uma tradição de pesquisa derivada dos estudos em ciência e tecnologia - conhecidos como Science, Technology and Society Studies (STS) -, especialmente da perspectiva das associações heterogêneas de John Law (1984, 2009, 2019), dos estudos feministas de tecnociência de Donna Haraway (1995) e da teoria ator-rede de Bruno Latour (2012).

Vale constar que Flusser não menciona que seus trabalhos pertencem à corrente da semiótica material, tampouco os estudos semiótico-materiais costumam agregar as considerações do autor. Pode-se dizer, inclusive, que seria anacrônica tal relação, dado que Flusser escreveu e publicou sua obra entre os anos 1960 e 1990, considerando que expressões como teoria ator-rede e semiótica material circulam apenas timidamente nos anos 1990 e se consolidam nos anos 2000. Diante disso, nossa proposta com o presente texto é, de modo retroativo, sugerir uma relação entre algumas reflexões de Flusser e o arcabouço teórico atualmente vinculado às semióticas materiais.

Objetivamos, assim, colaborar com uma construção robusta e densa que emerge da capacidade teórica da semiótica material, além de sugerir novos delineamentos possíveis de tal abordagem em construção. Acreditamos que ao propor correlações com os estudos flusserianos, somos capazes de contribuir para o amadurecimento da corrente semióticomaterial. Ademais, procuramos superar críticas a tal tipo de ecletismo teórico. Consideramos que sínteses e sincretismos são frutíferos - desde que cuidadosamente estudados, elaborados e argumentados - e que os prejuízos do dogmatismo são um risco ainda pior, especialmente tratando-se de Vilém Flusser, estudioso que buscou sincretizar Heidegger e Wittgenstein, filosofia continental e a analítica.

Aproximar o pensamento de Vilém Flusser à semiótica material é possível e interessante por vários motivos, como pelo caráter pós-humanista de ambos e pela atenção voltada sobretudo aos objetos do mundo. No entanto, aqui, chama-nos atenção a noção de caixa preta, especialmente. 0 conceito de caixa preta, derivado da Computação e da Engenharia, presente também na Cibernética, é tão central para o pensamento de Vilém Flusser (2013) quanto para a semiótica material e a teoria ator-rede (LATOUR, 2000; AKRICH, 1992), como explicaremos adiante. 
De antemão, para introduzir a questão aqui posta, vale apontar que Flusser (2013) caracteriza a caixa preta em termos de competência relativa ao funcionário:

A competência do aparelho deve ser superior à competência do funcionário [...]. A competência do fotógrafo deve ser apenas parte da competência do aparelho [...]. Um sistema assim tão complexo é jamais penetrado totalmente e pode chamar-se caixa preta (FLUSSER, 2013, n.p.).

Consta-se que para Flusser (2013), a crítica a respeito da imagem técnica deve visar o esclarecimento das caixas-pretas. Orientados por sua reflexão, acreditamos que este aspecto é capaz de dar conta da complexidade de temas como objetos, materialidades, tecnologias e design, especialmente nos estudos em Ciências da Comunicação. Tanto Vilém Flusser quanto os estudos em semiótica material esforçam-se em abrir caixas pretas e procuram desvendar e explicar a maneira de jogar com elas.

A partir disso, na próxima seção trazemos o que entendemos por semiótica material. Depois, argumentamos que a crítica de Flusser aos aparelhos é uma contribuição relevante à tal corrente semiótica. Seguimos, então, para uma observação específica da noção de caixa preta, atentando para aquilo que Vilém Flusser aponta que deve ser investigado, como o tipo de pensamento que se coloca. Na última seção, realizamos uma análise que denominamos de semiótica material de inspiração flusseriana, através do exame de uma função de aplicativos de celular: a automatização encadeada da reprodução de vídeos curtos, o autoplay dos Stories - especificamente observada no Instagram para este artigo.

\section{Lendo Vilém Flusser pelas lentes da semiótica material}

Para desenvolver a presente reflexão, debruçamo-nos sobre uma leitura aprofundada dos textos $O$ mundo codificado: por uma filosofia do design e da comunicação (FLUSSER, 2007) e, especialmente, Filosofia da caixa preta: ensaios para uma futura filosofia da fotografia (FLUSSER, 2013). O conceito de caixa-preta é especialmente explorado pelos estudos sobre ciência e tecnologia, com ênfase na tradição que se consolidou como STS, sobretudo na América do Norte - estudos sobre ciência, tecnologia e sociedade, em tradução nossa.

Tal tradição deu origem à teoria ator-rede e, eventualmente, ao que chamamos de semiótica material. Gostaríamos, então, de realizar uma leitura de Vilém Flusser permeada pelo caráter agregador da expressão semiótica material. Na presente seção, observamos a 
expressão, considerando-a útil e interessante teórico-metodologicamente para o estudo de caixas pretas. Além disso, temos o objetivo de demonstrar ao longo da reflexão os motivos pelos quais os textos de Vilém Flusser podem ser compreendidos como relevantes à semiótica material.

Raquel Manzanares, Ricardo Mattos e Rita Engler (2017) realizam um dos diferentes esforços de aproximação sistemática entre Vilém Flusser e Bruno Latour. Segundo os autores, além da tentativa de ambos pela construção de uma filosofia do design, Flusser e Latour se encontram na superação de uma forma moderna de pensamento acerca do design que incluiria, dentre outros aspectos, cautela, autoconsciência e moral (MANZANARES; MATTOS; ENGLER, 2017). Manzanares, Mattos e Engler (2017) concluem, ao estudar o pensamento dos autores, que "[...] precisamos compreender os produtos humanos para assimilarmos a essência da nossa existência, atividade essa que é primordial à filosofia." (MANZANARES; MATTOS; ENGLER, 2017, p. 11). Tal perspectiva pode ser relacionada, como pretendemos fazer em seção posterior do presente texto, com a crítica que Flusser propõe em Filosofia da caixa preta: ensaios para uma futura filosofia da fotografia (FLUSSER, 2013).

Enquanto isso, Erick Felinto (2019) também busca convergências entre Flusser e outros autores, especificamente, neste caso, com Walter Benjamin. Ele conclui que "[...] ambos operam com conceitos de vida e história que se estendem às coisas." (FELINTO, 2019, p. 109). A chave para tal convergência pode ser pensada através da ideia de póshumanismo. Podemos considerar tanto Flusser, quanto Benjamin - e também Latour como pensadores que incluem em seus esquemas e reflexões plantas, animais, monstros, minerais, entre outros.

John Law $(2009,2019)$ se refere à consideração desses diversos agentes como uma forma de heterogeneidade, pois observa o desenvolvimento de estudos que apresentam associações heterogêneas. Compreender a composição das coisas como associações heterogêneas é uma postura que Law (2019) deriva de suas leituras e encontros com Donna Haraway (1995) e a ambos se credita uma ideia de semiótica material. A expressão aparece inicialmente no texto Saberes localizados: a questão da ciência para o feminismo e o privilégio da perspectiva parcial de Haraway (1995) para caracterizar a relação entre significados e corpos.

Depois, a expressão "semiótica material" é utilizada por John Law $(2009,2019)$ como um termo guarda-chuva que busca enquadrar perspectivas que, assim como a teoria ator-rede, preocupam-se com tais tipos de associações heterogêneas. Por se tratarem de aspectos materiais, são caracterizados por uma certa relação entre a fluidez e a solidez e 
tudo aquilo que é possível construir a partir deles. 0 foco do trabalho elaborado por Law $(2009,2019)$ e que caracteriza tais estudos é o que ficou entendido como agência do nãohumano na teoria ator-rede.

0 não-humano para a teoria ator-rede de Bruno Latour (2012), por exemplo, aparece na temática da agência dos objetos. Trata-se da ação de determinado objeto que faz parte ativamente de uma relação entre outros objetos ou pessoas, que, por sua vez, agem congruentemente com a presença dele. Não se trata, aqui, de aceitar que objetos determinem a ação humana, mas de reconhecer que eles fazem parte da ação da rede como um todo. A teoria ator-rede supõe a ideia de que tudo aquilo que é estudado é um ator estudado por estar relacionado a outros atores ligados em uma rede. A ideia de rede evoca, assim, correlações. Em teoria ator-rede não há começo ou fim, causa ou efeito, apenas associações. Tal noção não é, de forma alguma, exclusiva ou inédita da teoria ator-rede. Ela aparece, de cerdo modo, em Flusser (2013): “Os aparelhos se programam mutuamente em hierarquia envelopante. Trata-se, nesse complexo de aparelhos, de caixa preta composta de caixas pretas." (FLUSSER, 2013, doc. não paginado). A concepção de envelopes e caixas pretas evoca as noções de articulação, rede e associação.

Nos STS, uma das definições mais interessantes para semiótica é dada por Madeleine Akrich e Bruno Latour (1992). Os autores se preocupam com a noção de meaning, que pode ser traduzida como significado, mas que inclui a concepção de pretensão e de meio (mean), diferente de termos como signified ou signification. Nas palavras de ambos, “[...] semiótica é o estudo da construção da ordem ou da construção dos caminhos e pode ser aplicada a configurações, máquinas, corpos e linguagens de programação, assim como a textos." (AKRICH; LATOUR, 1992, p. 259, tradução nossa ${ }^{1}$ ).

A teoria ator-rede é considerada, por John Law $(2009,2019)$, apenas uma dentre as várias formas de semiótica material. Para o autor (LAW, 2009, 2019), não existe uma teoria ator-rede de maneira concisa, mas uma série de estudos com alguns aspectos em comum e que se entrelaçam com outras tradições intelectuais. Por isso, Law (2009) admite que: “[...] é melhor falar de 'semiótica material' ao invés de 'teoria ator-rede'. Isto captura melhor a abertura, incerteza, revisibilidade e diversidade dos trabalhos mais interessantes." (LAW, 2009, p. 142, tradução nossa² ${ }^{2}$.

\footnotetext{
1 No original: [...] semiotics is the study of order building or path building and may be applied to settings, machines, bodies, and programming languages as well as texts.

2 No original: [...] it is better to talk of 'material semiotics' rather than 'actor network theory.' This better catches the openness, uncertainty, revisability, and diversity of the most interesting work.
} 
John Law $(2009,2019)$ usa o termo no plural, material semiotics. O plural é interessante no inglês para salientar a diversidade de perspectivas, no entanto, tal forma é incomum na língua portuguesa. A expressão semiótica, em língua portuguesa e com tradição brasileira, mesmo no singular, já pressupõe certa diversidade e é frequentemente usada como tradução para semiotics. Nesse sentido, optamos por uma tradução que flexiona em número, para o singular semiótica material. No entanto, quando o termo está adjetivando, como na expressão análise semiótica-material, trata-se de um adjetivo composto e, nesse caso, requer uso de hífen.

Diferente da teoria ator-rede, que acabou por adquirir um caráter unitário, centralizado em figuras como Bruno Latour e em textos prescritivos como Reagregando o social: uma introdução à Teoria do Ator-Rede (LATOUR, 2012), a semiótica material é deliberadamente um termo guarda-chuva, empregado com caráter inclusivo. Dentre a diversidade de autores/as que desenvolvem análises que poderiam ser categorizadas como semiótico-materiais, podemos incluir aqui, por exemplo, Hans Gumbrecht (2010) para quem a presença é constituinte da comunicação tanto quanto o sentido; James Gibson (2014), responsável pela elaboração do conceito de affordances, características materiais que condicionam a usabilidade, relevante para a noção de percepção do ambiente e dos objetos no design; e Tim Ingold (2012) que realiza crítica ao modelo hilemórfico aristotélico, que dualiza forma e matéria, para propor noções como coisa e vivacidade.

Vale constar que Flusser (2013) entende o funcionário como alguém emaranhado entre aparelhos, contra os quais joga. A relação entre funcionário e aparelho não é necessariamente material, mas a relação entre o fotógrafo e o aparelho fotográfico é, sendo que o mesmo ocorre com diversos outros aparelhos. Compreender, então, seus programas, esclarecer suas caixas pretas e experimentar com eles envolve uma incursão no mundo das materialidades.

\section{Flusser responde como criticar os aparelhos}

No que se refere às reflexões de Flusser, é essencial que se dê atenção à automaticidade dos aparelhos. Em Filosofia da caixa preta: ensaios para uma futura filosofia da fotografia (FLUSSER, 2013), o autor denuncia a incapacidade de uma crítica socioconstrutivista que é, nas palavras dele, sedutora: “[...] basta descobrir as intenções humanas que levaram a produção de aparelhos." (FLUSSER, 2013, doc. não paginado). Essa 
crítica é insuficiente, de acordo com o autor (FLUSSER, 2013), pois acaba por concluir questões menores e sobre as quais não há dúvidas, como, por exemplo, que o aparelho foi produzido sob os interesses do proprietário da fábrica, da ideologia americana etc.

No entanto, aparelhos escapam rápida e largamente às intenções humanas, seja de quem os cria ou de quem os usa. De acordo com o pensamento de Flusser (2013), o aparelho busca ser independente dos seres humanos, busca sua autonomia através da automação, visando ultrapassar a competência humana. É impossível, diante disso, realizar uma crítica que nega a automaticidade dos aparelhos. A automaticidade deve ser compreendida, deve ser ela mesma encarada como o alvo da crítica. Apenas assim podemos, orientados pela reflexão do autor, retomar o poder sobre os aparelhos.

Para Flusser (2013), existe um caminho para o fotógrafo lutar contra essa automação: agir contra o programa. Para tanto, é necessário conhecer seu funcionamento e praticar um comportamento experimental. Os fotógrafos experimentais “[...] tentam, conscientemente, obrigar o aparelho a produzir imagem informativa que não está em seu programa." (FLUSSER, 2013, doc. não paginado).

Flusser (2013) conclui: “O dever de toda a crítica dos aparelhos é mostrar a cretinice infra-humana dos aparelhos [...] transcender o totalitarismo robotizante dos aparelhos que está em vias de se preparar." (FLUSSER, 2013, doc. não paginado). A filosofia da fotografia deve, para o autor (FLUSSER, 2013), desmascarar o fato de que mesmo os interesses de fabricantes ou proprietários dos aparelhos estão a serviço de um programa de automação, de um tipo de pensamento, que culmina na vaziez do universo fotográfico.

É nessa proposta de crítica que Flusser vai além do pensamento de, por exemplo, Langdon Winner (1989). Winner (1989) argumenta que “[...] coisas técnicas têm qualidades políticas [...] incorporam formas específicas de poder e autoridade." (WINNER, 1989, p. 19, tradução nossa ${ }^{3}$ ). Neste contexto, enfoca-se no poder e autoridade que foram incorporados nas coisas técnicas por seus produtores ou fabricantes e que podem, a partir delas, ser exercidos.

Tal visão é similar à de John Law, apresentado anteriormente como um autor que se dedica ao estudo da semiótica material, em um dos seus primeiros textos, sobre a relação entre cartas náuticas, barcos e bússolas na construção de métodos de controle a distância no imperialismo português (LAW, 1984). Para Law (1984), foi o gerenciamento e a manutenção 
de tais objetos técnicos e heterogêneos que possibilitaram ao Império Português exercer controle, poder e autoridade durante o colonialismo.

É possível, a partir de uma inspiração flusseriana, argumentar que Winner (1989) está correto em dizer que artefatos têm política, no entanto, a crítica de Winner se resume a pensar a política imbricada nos artefatos por aqueles que os constroem. Curiosamente, outro texto de Winner (1993), intitulado Sobre abrir a caixa-preta e encontrá-la vazia, critica propriamente os estudos sobre ciência e tecnologia, sobretudo a postura conhecida como construção social da ciência e tecnologia, defendida por Bruno Latour e outros de seus colegas durante anos 1980.

A postura de Winner (1993), aqui, é de denunciar o esvaziamento, a despolitização e o comportamento escolástico de estudos que tratam da construção social da ciência e tecnologia da época, especialmente seu abandono de um projeto político, a falta de um objetivo. É, de certo modo, similar à crítica de Francisco Rüdiger (2015), que aponta no empirismo da teoria ator-rede um abandono abstrato e irreflexivo da crítica.

É na proposta crítica de Vilém Flusser que podemos triangulá-lo entre tais perspectivas. Nos termos de Flusser, podemos dizer que os estudos sobre a construção social da ciência e tecnologia buscam sobretudo as intenções humanas e negam a automaticidade e a programação dos aparelhos. Para conjecturarmos as reflexões de Flusser como relevantes aos estudos em semiótica material, precisamos considerar tais similaridades e diferenças entre ele e os campos de estudos que deram origem a tal abordagem.

A semiótica material não objetiva, como Flusser (2013), “[...] mostrar a cretinice infra-humana dos aparelhos [...]" (FLUSSER, 2013, doc. não paginado), mas também não se contenta em apenas descobrir intenções. Busca mostrar o que for necessário, inclusive a cretinice infra-humana. Semiótica material é uma expressão excelente para caracterizar ao menos a primeira etapa da proposta de ação de Flusser (2013): conhecer o funcionamento da caixa preta, esclarecê-la.

Flusser (2013) constata, ao ponderar sobre como funcionam as caixas pretas, que os humanos que trabalham com aparelhos e que os produzem podem, eles mesmos, tentar ir contra tais programas, podem empregar uma tentativa experimental. Tal pensamento pode ser comparado com a cautela referida no ensaio de Bruno Latour (2014): Um prometeu cauteloso. "As coisas já não são 'feitas' ou 'fabricadas', mas sim cuidadosamente - ou cautelosamente - elaboradas através do design." (LATOUR, 2014, p. 6). Como Manzanares, Mattos e Engler (2017) elencam em sua aproximação entre Latour e Flusser, a superação do 
funcionalismo moderno passa por transformações e buscas por agregar momentos de cautela e moralidade no design.

Ainda que Flusser apresente uma postura mais provocadora e convocatória, as duas visões podem ser postas em paralelo. E é por esta via que o pensamento de Vilém Flusser tem algo poderoso para oferecer à semiótica material: uma proposta de crítica que é ao mesmo tempo desafiadora e produtiva. Consideramos Flusser a chave para uma apropriação crítica da semiótica material.

\section{Flusser responde dilemas sobre o essencial à caixa preta}

Antes de prosseguirmos para nosso experimento de semiótica material de inspiração flusseriana, é válido realizarmos algumas considerações sobre o conceito de caixa preta. Nos anos 1970 e 1980, tanto Vilém Flusser quanto os estudos acerca da construção social da ciência e tecnologia, que depois desembocaram na semiótica material, convidamnos a abrir caixas pretas. A expressão é comum especialmente na engenharia e na computação e designa um objeto qualquer tratado apenas em termos de inputs e outputs, ou seja, cujo funcionamento interno pode ser ignorado por quem o usa e é, por design, ocultado, opaco, nebuloso etc.

Para Flusser, "Quem vê input e output vê o canal e não o processo codificador que se passa no interior da caixa preta." (FLUSSER, 2013, doc. não paginado, grifo do autor). Criticar a imagem técnica deve passar por tornar a caixa transparente. É a ignorância dos processos da caixa preta que tornam o fotógrafo suscetível à dominação.

Tornar a caixa transparente, ou abri-la, envolve superar sua análise em termos de inputs e outputs. É a partir daí que Flusser aprofunda sua análise pensando o aparelho fotográfico e a imagem técnica e fotográfica em sua relação com a escrita, com mitos, com a linearidade do texto, com o papel enquanto mídia de alta mobilidade, seu fascínio mágico, entre outros.

Nos estudos baseados na teoria ator-rede e em construção social da tecnologia, o verbo blackboxing - transformar uma rede de associações até então aberta e em construção em algo fechado, pronto, uma caixa preta - refere-se ao momento em que o design encerra seu trabalho. Em outras palavras, é quando os engenheiros da Kodak ou da Samsung encerram o design de um aparelho fotográfico ou celular e as fábricas já estão em fase de produção e envio às lojas. Em termos flusserianos, é o momento no qual cessa-se a programação do aparelho. A partir disso, a crítica socioconstrutivista, que Flusser (2013) 
considera insuficiente, já tem dificuldade de operação, pois se torna difícil descobrir as intenções por trás dos criadores, ao menos considerando o método dos estudos da construção social da tecnologia: a observação de engenheiras, engenheiros e designers trabalhando.

Madeleine Akrich (1992) considera o estudo de inventoras e inventores como seu principal método de pesquisa. No entanto, admite que "[...] a situação é diferente quando nos confrontamos com tecnologias estabilizadas, que foram 'black boxed'." (AKRICH, 1992, p. 211, tradução nossa ${ }^{4}$ ). Ademais, ela considera que o estudo do usuário não é útil, pois ele já está acostumado com a máquina, e sugere que

Alternativamente, podemos estudar disputas, ver o que acontece quando dispositivos dão errado, ou seguir os dispositivos à medida que são levados para outros países que são cultural ou historicamente diferentes do seu lugar de origem. (AKRICH, 1992, p. 211, tradução nossa5).

O trabalho de Akrich (1992) é considerado fundamental para os estudos da construção social da tecnologia e desaguaram na compreensão atual de teoria ator-rede. Tal postura, dedicada a compreender a tecnologia, é muito poderosa para investigar laboratórios, fábricas ou empresas. Se Bruno Latour realizasse um estudo sobre o aparelho fotográfico, acreditamos que ele iria à fábrica, não a uma exposição.

Em Ciência em ação, Latour (2000) descreve, do ponto de vista de seus estudos, como a ciência constrói caixas pretas. Tratam-se de coisas em geral que, por funcionarem bem para os propósitos aos quais foram elaboradas, são consideradas boas máquinas e podem ser assumidas assim por outras e outros. Caixas pretas são construídas por cientistas pois visam o alistamento de outras pessoas em seus sistemas, métodos e técnicas. 0 escrutínio de sua construção e das redes de associações que elas evocam e provocam é interessante, no entanto, depois de fechada ela se torna, no cotidiano do laboratório, um mero objeto com função determinada.

A teoria ator-rede - e, junto dela, boa parte das posturas em semiótica material preocupa-se com o momento de black boxing em si, mas também com uma fase anterior. Encontra seu limite nas caixas pretas. Quanto mais opaca, mais limitada. 0 não-humano tem agência, evidentemente, porém, no que diz respeito aos objetos técnicos, tal agência é

\footnotetext{
4 No original: [...] the situation is quite different when we are confronted with stabilized technologies that have been 'black boxed'.

5 No original: Alternatively, we may study disputes, look at what happens when devices go wrong, or follow the device as it moves into countries that are culturally or historically distant from its place of origin.
} 
pensada na diferença estritamente empírica entre seu input e output. Esta é, também, a crítica de Langdon Winner (1993) apresentada na seção anterior.

Por isso, a filosofia da caixa preta de Flusser (2013) é tão útil para a semiótica material, especialmente se a admitimos como uma proposta mais ampla que a teoria atorrede. Ao considerar a compreensão flusseriana de caixa preta, precisamos pensar em seus programas. Além de tornar as caixas pretas transparentes, a instrução teóricoepistemológica que Flusser oferece, aqui, é: "Quem quiser captar a essência do aparelho, deve procurar distinguir o aspecto instrumental do seu aspecto brinquedo [...]" (FLUSSER, 2013 doc. não paginado). Para o autor, instrumento é "simulação de um órgão do corpo humano que serve ao trabalho"; brinquedo é "objeto para jogar" e jogo é "atividade que tem fim em si mesma" (FLUSSER, 2013, doc. não paginado).

0 instrumental é, então, o aspecto do aparelho que tem propósito funcionalista, que serve ao trabalho. Já o aspecto essencial ao aparelho, o que devemos investigar para compreendê-lo e superá-lo, é o que nos coloca em uma postura lúdica, nos insere em uma relação pós-industrial. Desse modo, a nossa proposta de semiótica material de inspiração flusseriana não se preocupa apenas com o momento black boxing e anterior, mas também com os aspectos instrumental e essencial do aparelho.

\section{Um aparelho que é telefônico, fotográfico, audiovisual e computacional}

Em Imagens nos novos meios, texto que data de 1989 publicado em $O$ mundo codificado (FLUSSER, 2007), Vilém Flusser argumenta que "[...] os novos meios, da maneira como funcionam hoje, transformam as imagens em verdadeiros modelos de comportamento e fazem dos homens meros objetos." (FLUSSER, 2007, p. 159). Por "novos meios", Flusser (2007) refere-se à televisão, especialmente o videoteipe e a televisão à cabo, e aos meios digitais que estavam tornando-se acessíveis ao público geral com a Internet comercial.

Flusser (2007) se preocupa com as imagens que podem “[...] ser reproduzidas à vontade e alcançar cada receptor isolado, onde quer que ele esteja." (FLUSSER, 2007, p. 153). O autor acredita que tal avanço de imagens técnicas, quando elas podem ser transportadas à vontade, é problemático, pois quando “[...] o receptor não precisa distanciar-se de seu espaço privado para ser informado, isso quer dizer que o espaço público (a política) se tornou superficial." (FLUSSER, 2007, p. 153). Podemos entender que superficial, aqui, não é apenas no sentido de irrefletido, relativo a conhecimento ou 
pensamento superficial, mas, principalmente, no sentido de operar nas superfícies, como o papel ou a tela.

Consta-se que a pesquisa realizada pelo Comitê Gestor da Internet no Brasil (2019), denominada TIC Domicílios, notou que 93\% dos domicílios brasileiros possuem telefone celular. 0 aparelho telefônico é hoje mais presente que o rádio (62\%) e que o telefone fixo (24\%). Das TICs pesquisadas, só não é mais presente que a televisão (96\%). 0 aparelho telefônico celular, especialmente a forma como ele tomou a partir do smartphone e, nos últimos anos, com seu baixo custo e alta popularidade, é hoje um dos principais meios de comunicação (COMITÊ GESTOR DA INTERNET NO BRASIL, 2019). Neste contexto, parafraseando Flusser (2007), a política se tornou superficial.

$\mathrm{Na}$ presente seção, propomos, então, uma semiótica material de inspiração flusseriana do aparelho dito telefônico - dito, pois a telefonia é apenas uma das atividades que ele programa. Por convenção, podemos chamá-lo tanto de aparelho telefônico, aparelho celular - termos populares e que remetem a expressões nos textos de Flusser - ou mesmo de aparelho smartphone. Smartphone, talvez, seja ironicamente o termo mais adequado, já que a ingenuidade do funcionário e competência do aparelho são expressões que aparecem com frequência no texto de Flusser (2013), relação que a palavra smart (inteligente) sugere.

Em Filosofia da caixa preta (FLUSSER, 2013), a principal preocupação é que os aparelhos, por serem caixas pretas, permitem ao ser humano apenas jogar dentro de seu programa. A ação é, assim, automatizada. Se realizada de maneira irrestrita, acrítica, tanto a produção quanto a recepção da fotografia são ingênuas, suscetíveis ao programa do aparelho. Assim, Flusser (2013) descreve a complexidade do aparelho fotográfico:

O aparelho fotográfico é o primeiro, o mais simples e o relativamente mais transparente de todos os aparelhos. O fotógrafo é o primeiro 'funcionário', o mais ingênuo e o mais viável de ser analisado. (FLUSSER, 2013, n.p.).

No presente estudo que realizamos do aparelho telefônico, propomos uma redação inspirada em tal trecho. Podemos pensar assim: o aparelho celular é o último, o mais complexo e o relativamente menos transparente de todos os aparelhos. Quem usa o celular já talvez não seja mais nem funcionário, e não sabemos dizer quanto a sua ingenuidade, mas certamente sua análise é muito complexa.

Se pensarmos no aparelho fotográfico com o qual Flusser (2013) escreveu sua Filosofia da caixa preta, nos anos 1980, o smartphone sem dúvida é um aparelho muito complexo e pouco transparente. 0 aparelho fotográfico fabricado na época tem um corpo 
pesado, com frequência feito de metal. A lente fotográfica é uma adjacência, normalmente é cambiável, seu vidro chama atenção para seu caráter óptico e seus anéis para seu caráter mecânico. Seus botões têm cada um uma função mecânica e alguns modelos até mesmo uma alavanca para avançar o filme. 0 smartphone, por outro lado, é inteiramente desenhado para ser elegante. Tem o tamanho ideal para ser utilizado com apenas uma mão e guardado facilmente no bolso. É tão fino e tão leve quanto os fabricantes conseguem produzi-lo. Se fosse tecnologicamente viável, seria fino como papel.

Com o avanço na tecnologia de sensores, os minúsculos sensores fotográficos embutidos no smartphone têm muito mais pontos de resolução do que os largos filmes fotográficos têm grãos de prata. 0 programa do aparelho celular faz da caçada pela fotografia algo tão automático que sequer exige que seu funcionário o gire para fazer um autorretrato, os smartphones tem dois aparelhos fotográficos embutidos. Os mais recentes têm no máximo três botões e apenas um deles é essencial, o de ligá-lo, que também geralmente serve para bloquear a tela. Os outros dois controlam o volume, função que também pode ser feita na tela, dependendo de seu nível de software. Exceto tais botões, todo o resto da interação é feita na tela através do toque, interação superficial.

Vilém Flusser (2013), sobre a fotografia, destaca o fato de ela ser folha de papel. Tal questão midiática de distribuição distingue a fotografia de outras imagens técnicas. No entanto, o aparelho fotográfico, agora embutido junto do aparelho de exibição, conseguiu o feito de tornar-se mais prático e tão superficial quanto uma folha de papel. Se transportar uma folha de papel já era algo simples e permitia à fotografia capacidade ímpar de distribuição, agora uma fotografia sequer precisa ser passada de mão em mão, pois já está virtualmente em todas as mãos.

Omite-se até agora, em tal descrição, uma das mais importantes características de tal aparelho. Trata-se de característica desenhada para ser discreta. Ele conta com uma antena interna, oculta e embutida. A antena é microeletrônica, está lá no lugar do que, décadas atrás, seria um cabo. Ela é capaz de conectá-lo à rede telefônica e à Internet. É ação mágica e ritualística. 0 sinal é como espírito, inserir uma senha é como rito.

Através dessa conexão o aparelho telefônico tem acesso não a um, mas a inúmeros jogos. Nesse sentido, trata-se de uma caixa preta que desdobra em si mesma inúmeras outras caixas pretas, e diferentes jogos podem ter lugar entre funcionário e smartphone. 0 aplicativo Instagram é um bom exemplo de plataforma que corrobora tais características. Isso porque o Instagram é ele mesmo outro aparelho. 0 pensamento que ele simula é imagético, não apenas fotográfico, mas também audiovisual. 0 nome não poderia ser outro, 
e refletir sobre ele já é por si só interessante: Insta- refere-se ao instante, ao instantâneo e automático; -gram é sufixo que, como na palavra telegrama, refere-se ao escrito ou gravado. O Instagram é aquilo que foi gravado instantânea e automaticamente. Nesse sentido, tanto fotografar usando o smartphone quanto expor a fotografia no Instagram tem a ver com o que Vilém Flusser diz a respeito da democratização do ato fotográfico. "Quanto mais houver gente fotografando, tanto mais difícil se tornará o deciframento de fotografias, já que todos acreditam saber fazê-las." (FLUSSER, 2013, doc. não paginado).

Nessa esteira, ao passo que as fotografias são realizadas sem a devida postura crítica, sem a experimentação e sem certa transparência da caixa preta, mais se produzem fotografias e, estranhamente, mais difícil se torna compreendê-las. O Instagram é, assim, um dos lugares mais complexos onde se pode observar uma fotografia para decifrá-la. É onde o aparelho fotográfico reproduz seu tipo de pensamento sem freios.

No entanto, várias são as diferenças entre aparelho fotográfico e o Instagram, evidentemente. Uma das principais é que, para além de estar embutido em um aparelho que é fotográfico, está em um aparelho que é também conectado. Serve, então, tanto para expor quanto para ver. Observamos, de modo específico, uma das galerias que o Instagram nos apresenta chamada Stories: imagens ou vídeos curtos, de até quinze segundos, que são reproduzidos em sequência, automaticamente, embaralhando artistas, familiares e publicidade, no mesmo papel e no mesmo ritmo. Examinando a função Stories é onde buscamos tensionar alguns conceitos propostos por Flusser (2013).

Em Filosofia da caixa preta: ensaios para uma futura filosofia da fotografia, Flusser (2013) elenca quatro estruturas fundamentais de discurso:

1. os receptores cercam o emissor em forma de semicírculo, como no teatro; 2. o emissor distribui a informação entre retransmissores, que a purificam de ruídos, para retransmiti-la a receptores, como no exército ou feudalismo; 3. o emissor distribui a informação entre círculos dialógicos, que a inserem em sínteses de informação nova, como na ciência; 4. o emissor emite a informação rumo ao espaço vazio, para ser captada por quem nele se encontra, como na rádio. (FLUSSER, 2013, n.p.).

Cada estrutura corresponde a uma situação cultural, segundo o autor (FLUSSER, 2013). A primeira, é responsável, a segunda é autoritária, a terceira é progressista e a quarta é massificada. Para o autor (FLUSSER, 2013), a distribuição das fotografias se dá pelo quarto método discursivo, similar ao rádio. 
Na fotografia veiculada através do aparelho smartphone não é diferente. Entretanto, algumas coisas são moduladas em formato diferente. 0 emissor não transmite a informação exatamente em espaço vazio e, especialmente, quem nele se encontra não está lá por decisão deliberada e consciente.

Existe ainda outro aparelho embutido entre os já mencionados. Referimo-nos ao algoritmo de distribuição de conteúdo em plataformas de mídia social. Tal aparelho é propriamente o responsável para que, na situação massificada de conexão, o espaço onde a informação é veiculada não seja exatamente espaço vazio. Pelo contrário, é largamente povoado e o que nele circula é amplamente manipulado. Podemos buscar conceitualização de algoritmo em autoras como José van Dijck (2013):

[...] mídias sociais são inevitavelmente sistemas automatizados que engenham e manipulam conexões. Para serem capazes de reconhecer o que as pessoas querem e gostam, Facebook e outras plataformas rastreiam desejos codificando o relacionamento entre pessoas, coisas e ideias em algoritmos. (DIJCK, 2013, p. 12, tradução nossa ${ }^{6}$ ).

Acreditamos que tal perspectiva, isto é, a de que o algoritmo é elemento de software responsável por engenhar as relações entre as pessoas e coisas conectadas, complementa nossa análise no seguinte sentido: a fotografia que circula online no Instagram através do smartphone não circula livremente. O lugar que antes tinha a folha de papel, agora é de um aparelho. Trata-se de versão pós-industrial da folha de papel, automatizada e automatizante. O aparelho é dono tanto do momento de produção quanto do momento de recepção.

Encadeia-se uma fotografia atrás da outra, um vídeo curto atrás do outro, até que se esgotem mutuamente. A pouca opção de reação e interação - responder com uma pequena figura, outra foto ou algumas palavras - gera mais dados para o aparelho. Os dados que qualquer interação gera servem como input para mais uma rodada. Na mídia algorítmica, cada interação deixa o aparelho mais competente e sua decifração mais complexa.

\section{Considerações finais}

Ainda que muito crítico e talvez até pessimista, Vilém Flusser raramente é fatalista em suas análises. Costuma encerrá-las com perspectivas que reforcem existências vívidas e

\footnotetext{
${ }^{6}$ No original: [...] social media are inevitably automated systems that engineer and manipulate connections. In order to be able to recognize what people want and like, Facebook and other platforms track desires by coding relationships between people, things, and ideas into algorithms.
} 
ativas, mesmo em um mundo de coisas mais competentes que nós. Em Imagens nos novos meios, Flusser (2007) insiste que "[...] os meios podem funcionar de maneira diferente, a fim de transformar as imagens em portadoras e os homens em designers de significados." (FLUSSER, 2007, p. 159).

0 reforço à vida e atividade aqui é, então, conhecer o funcionamento da caixa preta, superar o seu programa, tornar-se competente e experimentar. Para jogar de maneira experimental, a fotografia nos Stories deve convidar para interações não dataficáveis, exteriores à plataforma. Que não apenas use significados, mas que os construa.

Uma semiótica material de inspiração flusseriana é aquela que enfoca na busca por examinar sobretudo a problemática de subordinação humana nas associações heterogêneas, para além de usos, apropriações e construções das tecnologias ou da relação entre humanos e não-humanos. A contemplação flusseriana em uma investigação semiótico-material visa entender como se desenvolve um tipo de pensamento infra-humano.

\section{Referências}

AKRICH, M.; LATOUR, B. A summary of a convenient vocabulary for the semiotics of human and nonhuman assemblies. In: BIJKER, W. E.; LAW, J. Shaping technology / building society: studies in Sociotechnical Change. Cambridge: The MIT Press, 1992. p. 259-264.

AKRICH, M. The De-Scription of technical objects. In: BIJKER, W. E.; LAW, J. Shaping technology / building society: studies in sociotechnical change. Cambridge: The MIT Press, 1992. p. 205-224.

COMITÊ GESTOR DA INTERNET NO BRASIL. TIC Domicílios: pesquisa sobre o uso das Tecnologias de Informação e Comunicação nos domicílios brasileiros 2018. São Paulo: Comitê Gestor da Internet no Brasil, 2019.

DIJCK, J. van. The Culture of Connectivity: a critical history of Social Media. Nova York: Oxford University Press, 2013.

FELINTO, E. "Vejo Édipo em minha horta": natureza e cultura em Flusser e Benjamin. Artefilosofia, Ouro Preto, n. 26, p. 100-111, 2019.

FLUSSER, V. Filosofia da caixa preta: ensaios para uma futura filosofia da fotografia. São Paulo: Annablume, 2013.

FLUSSER, V. 0 mundo codificado: por uma filosofia do design e da comunicação. São Paulo: Cosac Naify, 2007.

GIBSON, J. J. The ecological approach to visual perception. Nova York: Psychology Press, 2014. 
GUMBRECHT, H. U. Produção de Presença: o que o sentido não consegue transmitir. Rio de Janeiro: Contraponto, 2010.

HARAWAY, D. Saberes localizados: a questão da ciência para o feminismo e o privilégio da perspectiva parcial. Cadernos Pagu, Campinas, n. 5, p. 7-41, 1995.

INGOLD, T. Trazendo as coisas de volta à vida: emaranhados criativos num mundo de materiais. Horizontes Antropológicos, Porto Alegre, v. 18, n. 37, p. 25-44, 2012.

LATOUR, B. Ciência em ação. São Paulo: UNESP, 2000.

LATOUR, B. Reagregando o social: uma introdução à Teoria do Ator-Rede. Salvador: EDUFBA, 2012.

LATOUR, B. Um Prometeu cauteloso? Agitprop, São Paulo, v. 6, n. 58, p. 1-21, 2014.

LAW, J. Actor Network Theory and Material Semiotics. In: TURNER, B. S. The new blackwell companion to Social Theory. Hoboken: John Wiley \& Sons, 2009. cap. 7, p. 141-158.

LAW, J. Material Semiotics. Guovdageaidnu, 30th Jan. 2019. Disponível em:

https://web.archive.org/web/20200131144737/http://heterogeneities.net/publications/L aw2019MaterialSemiotics.pdf. Acesso em: 27 maio 2020.

LAW, J. On the Methods of Long-Distance Control: vessels, navigation and the Portuguese route to India. The Sociological Review, [s. l.], v. 32, n. 1, p. 234-263, 1984.

MANZANARES, R. D.; MATTOS, R. P.; ENGLER, R. C. Vilém Flusser e Bruno Latour: duas abordagens à filosofia do design. In: COLÓQUIO INTERNACIONAL DE DESIGN, 2017, São Paulo. Anais [...]. São Paulo: Blucher, 2017. p. 1-13.

RÜDIGER, F. Contra o conexionismo abstrato: réplica a André Lemos. MATRIZes, São Paulo, v. 9, n. 2, p. 127-142, 2015.

WINNER, L. The Whale and the Reactor: a search for limits in an age of High Technology. Chicago: The University of Chicago Press, 1989.

WINNER, L. Upon opening the black box and finding it empty: social constructivism and the Philosophy of Technology. Science, Technology, \& Human Values, [s. l.], v. 18, n. 3, p. 362378, 1993.

\title{
A world of things more competent than us: opening black boxes and material semiotics in Vilém Flusser
}

\begin{abstract}
Social construction of science and technology studies pay attention to black boxes and its operation. Recently, authors like John Law have suggested the notion of material semiotics to put
\end{abstract}


together considerations about the materiality of objects in analysis. In this paper, we intent to argue about how Vilém Flusser can retroactively be considered a thinker attentive to aspects of material semiotics and about how his critical perspective can contribute with such approach. Finally, to illustrate our view, we propose what can be called a Flusserian inspired material semiotic analysis on the smartphone device and the Stories function in the Instagram app. It concludes that a material semiotic of Flusserian inspiration is one that seeks to examine how an infrahuman type of thought develops in heterogeneous associations.

\section{Keywords}

Vilém Flusser. Material semiotics. Black box. Smartphone.

Recebido em 30/05/2020

Aceito em 13/06/2020 